\title{
ÍVHEGESZTÉSI ELJÁRÁSVÁLTOZATOK FEJLESZTÉSEI
}

\section{DEVELOPMENTS OF ARC WELDING PROCESS VARIANTS}

\author{
Bitay Enikö ${ }^{1}$, Bagyinszki Gyula ${ }^{2}$ \\ ${ }^{1}$ Sapientia - Erdélyi Magyar Tudományegyetem, Marosvásárhelyi Kar, Románia, \\ 540485 Marosvásárhely (Koronka), Segesvári út 1.C., ebitay@ms.sapientia.ro \\ ${ }^{2}$ Óbudai Egyetem, Bánki Donát Gépész és Biztonságtechnikai Mérnöki Kar, \\ Magyarország, 1081 Budapest, Népszínház u.8, bagyinszki.gyula@bgk.uni-obuda.hu
}

\begin{abstract}
It can conclude the application rate of welding processes on base the used electrodes numbers. The used electrodes for high strength steels are $65 \%$ of solid wire, $33 \%$ of cored wire and just $2 \%$ of the consumable electrode. These ratios are representative of the larger productivity reduce costs and competitiveness in pursuit of demand. This article reviews the main excerpts of the variants welding process developments.
\end{abstract}

Keywords: fusion welding, consumables, shielding gas, material transfer, power supply

\section{Összefoglalás}

Az ívhegesztési eljárásváltozatok alkalmazási arányára a hozaganyag felhasználásból lehet leginkább következtetést levonni. A növelt szilárdságú acélok hegesztéséhez felhasznált hozaganyag $65 \%$-a tömör huzal, $33 \%$-a porbeles elektródahuzal és mindössze $2 \%$-a bevont elektróda. Ezek az arányok jól jellemzik a nagyobb termelékenységre, a költségek csökkentésére és versenyképességre törekvés igényét. Ez a cikk az ívhegesztés főbb eljárásváltozatainak fejlesztéseit tekinti át kivonatosan.

Kulcsszavak: ömlesztö hegesztés, hozaganyag, védőgáz, anyagátmenet, áramforrás

\section{Fogyóelektródás eljárások}

Az MSZ EN ISO 4063 szerint 131-es, 132-es és 133-as jelü fogyóelektródás, semleges (Ar, He) védőgázos (MIG/Metall Inert Gas/) ívhegesztésekre jellemzö, hogy teker-cselt (131-es tömör, 132-es hegesztőpor-, 133-as fémpor-töltetü) hozaganyagot alkalmaz. A nagyobb védőgázköltségek miatt könnyü- és színesfémekhez, ill. erösen ötvözött acélokhoz célszerü.

A 135-ös, a 136-os és a 138-as számjelü fogyóelektródás, aktív védőgázos (MAG/Metall Active Gas/) ívhegesztések közül a leolvadó (135-ösnél tömör, 136-osnál hegesztőpor-, 138-asnál fémportöltetü) huzal reakcióképessé váló atmo-szférában jut az ömledékbe (hegfürdőbe). Elrendezésében a 72-es számjelü elektrosalakhegesztésre hasonlító, 73-as számjelü elektro-gázhegesztés függőleges kényszerhelyzetü MAG-hegesztés.

$\mathrm{Az}$ egykomponensü $\mathrm{CO}_{2}$ védőgázt háttérbe szorító keverék védőgázos hegesztésnél az argon hatására (pl. $82 \%$ Ar $+18 \% \mathrm{CO}_{2}$ ) javul(nak) az ívstabilitás, az anyagátvitel, a varratalak ill. -felület, a varratanyag mecha-nikai tulajdonságai, és csökken a fröcskölés. Növelt áramerősség 
esetén legfeljebb $25 \quad \% \quad \mathrm{CO}_{2}$-tartalomig biztosítható a rövidzárlat nélküli anyagátmenet.

A kettősgázfúvókás fogyóelektródás ívhegesztésnél vagy MAGCI-hegesztésnél egy külső fúvókán keresztül szén-dioxidot (C), egy belső fúvókán át argont (I) vezetnek az ív köré. Az argon gázburok a leolvadó tömör vagy porbeles huzalvég környezetében létesít kedvező semleges védőgáz atmoszférát, elősegítve a finomcseppes anyagátvitelt. A keverék védőgázas ívhegesztéshez képest fordított a drágább Ar és az olcsóbb $\mathrm{CO}_{2}$ felhasználásának aránya, ami javítja az eljárás gazdaságossági mutatóit. Védőgázkeverő helyett viszont speciális, kissé „robosztus” hegesztőfejet igényel.

A háromkomponensü $\left(\mathrm{Ar}+\mathrm{CO}_{2}+\mathrm{O}_{2}\right)$ védő-gázban már viszonylag kis áramerősségnél is létrejön a rövidzárlat nélküli csepp-átmenet. Héliumot is adagolva a gázkeve-rékhez (pl. $65 \% \mathrm{Ar}+8$ $\left.\% \mathrm{CO}_{2}+0,5 \% \mathrm{O}_{2}+26,5 \% \mathrm{He}\right)$, mélyebb beolvadás és nagyobb leolvadási teljesítmény érhető el. Ezzel a forgóíves anyagátmenet is megvalósítható, aminek feltételei: i $>300 \mathrm{~A} / \mathrm{mm}^{2}, \mathrm{P}>20 \mathrm{~kW}$ (megfelelő áramforrás), $\mathrm{V}_{\text {huzal }}>20 \mathrm{~m} / \mathrm{min}$ (alkalmas huzalelőtoló). Ez az ún. T.I.M.E.Process (Transferred Ionized Molten Energy Process, azaz ,átvitt ionizált ömledék energia") eljárásváltozat. Elsősorban vastag lemezek vízszintes helyzetű gépi hegesztésénél alkalmazzák.

A védőgáz jelentősen befolyásolja az anyagátmenetet, a rövidzárlati jelenségeket, az ömledék oxidációs folyamatait és a beolvadási mélységet. Az ívformákkal összefüggő anyagátvitel a védőgáztól és a hegesztési jellemzőktől függően többféle lehet, amire az eljárás számjelét kiegészítő betüjel is utalhat: D - dip or short-circuit transfer (durvacseppes vagy rövidzárlatos anyagátvitel), G - globular transfer (gömbcseppes anyagátvitel), S - spray transfer (permetszerü anyagátvitel), $\mathrm{P}-$ pulsed transfer (impulzusos anyagátvitel).

Impulzusos ívvel - az impulzusok periodicitásának beállításával - irányított cseppátmenet jön létre. Az alapáram akadályozza az ömledék és az elektródavég megdermedését, míg az erősebb áramimpulzus hatására egy vagy több cseppben megy át az anyag az ömledékbe. Semleges vagy nagy Ar-tartalmú védőgáz szükséges hozzá.

Gazdaság(osság)i és környezetvédelmi okok miatt az alkalmazott lemezvastagságok csökkennek. Az előgyártás költségeinek csökkentése érdekében a szerkezetek tervezői nagyobb türéseket engednek meg, ennek eredményeként azonban a hegesztőtechnológus gyártás közben a résáthidaló képesség problémájával szembesül.

Vékony lemezek, illetve nagy illesztési hézag esetén alkalmazható az a váltakozó áramú megoldás, amelynél az elektróda negatív polaritása alatt - a nagyobb hőterhelés miatt - a képződő csepp nagyobb méretü, ami jó résáthidaló képességet tesz lehetővé. Azonban a hőbevitel és a beolvadási mélység kisebb lesz. A pozitív és negatív polaritás aránya változtatható, ezáltal a hőbevitel és a leolvadás széles határok között kézben tartható. A MIG/MAG-lézer- (hibrid-)hegesztés a jobb résáthidaló-képességü fogyóelektródás védőgázos ívhegesztés és a mélyebb beolvadású lézerhegesztés kombinálása.

A következő igény a hő által okozott alakváltozás, az elhúzódás kis értéken tartása, miáltal sokkal pontosabb szerkezetek gyárthatók, illetve a visszamaradó feszültségek értéke csökkenthető. Ezekért a feszültségekért is a hegesztési hőbevitel felelős és a szerkezetet külső terhelés hiányában is igénybe veszik.

A CMT (Cold Metal Transfer, azaz Hideg FémÁtvitel) eljárásváltozat egy MIG/MAG mártogató-anyagátvitelü ívfolyamat, mely rövidzárlatos hegesztés kis hőbevitellel, „mechanikus” elvü 
cseppleválasztással. Az eljárásváltozat föbb jellemzői: szabályzási rendszerbe integrált huzalelötolási módszer, fröcskölésmentes hegesztési folyamat, nagyon alacsony höbevitel, stabil ív.

Következő fontos szempont a fröcskölés csökkentése, ami több fogyóelektródás eljárásváltozatnál elkerülhetetlen, bár megfelelő védőgázzal, helyes paraméter beállítással és pisztolyvezetéssel jelentősen csökkenthetö. Az STT (Surface Tension Transfer, azaz Felületi Feszültségü Átvitel) eljárásváltozat anyagátvitelében a felületi feszültség kap nagyobb szerepet. Alkalmas elektronikával komplex áramerősség-idő függvény valósítható meg.

\section{Nemfogyóelektródás eljárások}

A 14-es számjelü nem fogyóelektródás, védőgázos ívhegesztéseknél egy rendszerint oxidötvözésű volfrámelektróda és a hegesztendő anyagok között ég az ív, miközben az ömledéket semleges (a 141-es TIG- /Tungsten Inert Gas-/ hegesztésnél, a 142-es és a 143-as változatnál), redukáló (145-ös és 146-os változatnál) vagy aktív komponenst is tartalmazó (147-es változatnál) védőgázburok védi. Ívgyújtásra egy nagyfrekvenciás, nagyfeszültségü tápegység szolgál, amely szikrakisülés révén ionizálja az ívközt és ezzel lehetővé teszi az ív begyújtását az elektróda és a munkadarab összeérintése (ill. ebböl adódható szennyezés) nélkül. Alkalmas elektronikával - szabályozottan kicsi kezdő árammal - a kontakt ívgyújtás is lehetséges.

A 142-es autogén változathoz nem szükséges huzal vagy pálca hozaganyagot (141-es és 145-ös változatnál tömör, 143-as és 146-os változatnál porbeles) kézzel vagy huzaladagoló egység segítségével lehet az ívbe vezetni. Az eljárás drága és különleges anyagok hegesztéséhez használatos, föként a gyökvarratokhoz. Váltakozóáramú változata lehetővé teszi - a stabil felületi oxidréteg megbontása révén - alumínium hegesztését is.

Az ATIG-hegesztés aktiválóporos TIGhegesztés, ami jelentős beolvadási mélység növekményt produkál a TIG-hegesztéshez képest. Az aktiválóport $\left(\mathrm{TiO}_{2}, \mathrm{SiO}_{2}, \mathrm{Fe}_{2} \mathrm{O}_{3}\right)$ igen kis rétegvastagságban, manuálisan vagy gépi segítséggel viszik fel a felületre. $\mathrm{Az}$ ATIG-hegesztéshez hasonló hatások érhetők el az FBTIG (Flux-Bonded TIG) azaz porbevonatos TIG-hegesztéssel.

Ugyancsak nemfogyóelektródás, védőgázos eljárás a 15-ös számjelü plazmaívhegesztés, melynél elektromos ív segítségével ionizált gázt alkalmaznak hőforrásként. Hegesztés közben semleges védőgázburok védi a varratképződés helyét a környezeti hatásoktól. A jellemzö áramerősség-tartomány szerint megkülönböztethető:

- kisáramú $(0,1 \ldots 20 \mathrm{~A})$ vagy mikroplazmahegesztés, ami a vékony $(0,02 \ldots 1,5 \mathrm{~mm})$ anyagok kötőeljárása, és a kis áram esetén is stabil ívet biztosít;

- középáramú $(20 \ldots 100$ A) vagy beolvasztó- („melt-in”) technikájú hegesztés, elsősorban kézi plazmaívhegesztéshez;

- nagyáramú (100 A feletti) vagy kulcslyuk- (,key-hole”) technikájú hegesztés, gépesített plazmaívhegesztéshez.

Hibrid-eljárásváltozatai a következők:

- plazma-MIG-hegesztés: a MIG-hegesztés ívoszlopa köré stabilizáló plazmaívet vezetve, nagy huzalkinyúlással nagy fajlagos leolvadás érhető el, ill. a hegesztési sebesség is jelentősen megnövelhetö;

- plazma-TIG-hegesztés: föként gépesített hegesztésekhez, a hegesztési sebesség és a varratminőség optimalizálása céljából.

- elkülönített lézer- és plazmafejjel megvalósuló, közös munkafelületre irányított plazma-lézer hegesztés;

- közös hatásvonalú plazma-lézer hegesztés, ahol a fókuszolt lézersugárzás hozzávezetése a $\mathrm{W}$-elektróda kúpos üregén, ill. a plazmaíven keresztül valósul meg. 


\section{3. Ívhegesztő áramforrások}

Akár kézi, akár gépesített (robotosított) hegesztésről legyen szó, fontos hogy a korszerü áramforrások széles tartományban szabályozhatók legyenek, kompenzálják a „szerényebb" hegesztői képességeket is, továbbá akár a WPS betartását is "ki tudják kényszeríteni”. A több eljárásra ill. impulzustechnikára is alkalmas, polaritásváltós, digitális irányítású, inverteres hegesztőgépek ,tudják” a MIG/MAG, a porbeles huzalos önvédő, a MMA (beleértve a cellulóz bevonatú elektródást) és TIG hegesztést, valamint az ívgyalulást is. Pl. $60 \%$-os bekapcsolási idő $(\mathrm{X})$ esetén $500 \mathrm{~A}$, vagy $\mathrm{X}=100 \%$ mellett $300 \mathrm{~A}$ terhelést bírnak, zárt rendszerü vízhütőt alkalmazva.

A fejlesztések meghatározó tényezői a digitális jelprocesszorok és a megfelelő szoftver által felügyelt szinergikus függvények. Ezek a hardver változtatása nélkül növelik a hegesztés pontosságát és reprodukálhatóságát, így alapvető feladat meghatározni és újragenerálni elektronikus formában a hegesztési paramétereket. Ha a pillanatnyi aktuális értékek rendelkezésre állnak, úgy bármikor automatikusan állíthatók a célértékek elérése érdekében. A digitális hegesztéstechnológia révén a felhasználók tökéletesen illeszteni tudják a rendszert a különböző anyagminőségekhez, hegesztőanyagokhoz, védőgázokhoz és eljárás-paraméterekhez.

További innováció a hegesztő áramforrások vezeték nélküli irányítása. $\mathrm{Pl}$. egy tablet PC-re telepített szoftver WLAN kapcsolaton keresztül központi irányítást és ellenőrzést tesz lehetővé az erre alkalmas áramforrásoknál. Így nem szükségesek lokális irányító panelek minden egyes áramforrásnál. A teljes körüen adminisztráló és analizáló szoftver ezen kívül lehetőséget nyújt a hegesztési adatok és a szinergikus függvények grafikus kiértékelésére is.

\section{Következtetések}

Az ömlesztő hegesztési eljárások között a legfontosabbak az ívhegesztések, ezt még a számjelölésük 1-es kezdőszáma is hangsúlyozza. Az ipari igények az utóbbi időben a védőgázos eljárások felé fordultak, melyeknél nem csak a gázok és a munkarend, hanem a fejlett elektronikájú gépek is befolyásolják a varratképzés minőségét.

\section{Szakirodalmi hivatkozások}

[1] Bagyinszki Gyula, Bitay Enikő: Hegesztéstechnika I. Eljárások és gépesités, Erdélyi Múzeum-Egyesület, Kolozsvár, 2010 (ISBN 978-606-8178-04-2)

[2] Bagyinszki Gyula, Bitay Enikő: Hegesztéstechnika II. Berendezések és mérések, Erdélyi Múzeum-Egyesület, Kolozsvár, 2010 (ISBN 978-606-8178-04-2)

[3] Komócsin Mihály: A hegesztőeljárások fejlödése a közelmúltban, Miskolci Egyetem

[4] Somoskői Gábor: Kis hőbevitelü hegesztés elvi alapjai és gyakorlati alkalmazásai, OGÉT 2012

[5] Somoskői Gábor: Kis teljesitményü eljárásváltozatok és az anyagátvitel módjai a fogyóelektródás hegesztés területén, Gép LXIV. évfolyam 8. szám, 31-34. oldal

[6] Dobránszky János, Sándor Tamás, Magasdi Attila: $A z$ AVI-hegesztés különleges eljárásváltozatai: az ATIG-hegesztés és az FBTIG-hegesztés, MTA-BME Fémtechnológiai Kutatócsoport 